\title{
Cherishing and Clarifying Difference
}

\author{
Philip McCosker and Ed Kessler
}

T he articles gathered together in this section are the result of a panel discussion of a Roman Catholic text "The Gifts and the Calling of God are Irrevocable (Rom 11. 29)": A Reflection on Theological Questions Pertaining to Catholic-Jewish Relations on the Occasion of the 50th Anniversary of "Nostra Aetate" (No. 4)', which was co-sponsored jointly by the Chapel, Von Hügel Institute and Woolf Institute at St Edmund's College, Cambridge, in January 2016. The text itself was published in December 2015 by the Vatican's Pontifical Commission for Religious Relations with the Jews.

That such a joint venture would have been virtually impossible fifty years ago is eloquent witness to the groundbreaking nature of Nostra Aetate and the way it has transformed not only Christian-Jewish relations, but interreligious relations much more broadly. Published in October 1965 at Vatican II, Nostra Aetate achieved nothing less than a radical reversal of what Jules Isaac called the Church's ancient 'teaching of contempt' against Jews and Judaism and offered a renewed vision of the continuing role of the Jewish people in God's plan of salvation for all humanity. The fact that theologies of religious pluralism as well as comparative theologies now exist, not to mention countless associated practical initiatives all over the world, can be linked to that short watershed document of the Second Vatican Council. By its encouragement of 'dialogue and collaboration' with adherents of 'non-Christian religions' it fundamentally altered the relation between Christianity and other faiths from one of mutually exclusive opposition to one of inclusive textured difference; trading in suspicion, hostility, and persecution for dialogue, mutual learning, and collaboration.

Despite such great and game-changing progress in the last fifty years, much remains to be done and clarified, as our authors make clear in their discussion and interrogations of the new text. The question of supersessionism looms large in these articles. Also known as replacement theology, supersessionism is the traditional Christian teaching that with the coming of Jesus Christ the Church, as the True Israel (verus Israel), has 
replaced the Jewish people and that God's covenant with them has come to an end. In the rush to appreciation and collaboration with the religious 'other', the differences between faith traditions, and their ways of talking about those differences, need to be clarified and respected. In many ways the new document represents a deepening of reflection on the nature of the difference between Judaism and Christianity, and thus other faith traditions.

The new text is introduced by Henry Wansbrough OSB. He sets it against the background of centuries of Christian institutional anti-Semitism, and charts the key stages in the movement towards respect and collaboration since Nostra Aetate, focusing in particular on the 1995 text The Jewish People and their Sacred Scriptures in the Christian Bible, produced by the Pontifical Biblical Commission. He notes the change of discourse from interreligious dialogue to intrareligious collaboration, with the growing emphasis within Catholic theology on the ongoing covenant with Jews. As he puts it 'Jews are most dear to God', quoting from Nostra Aetate.

Supersessionist theologies are themselves superseded and rejected in the new text, as Gavin D'Costa underlines, in its key emphasis on the irrevocable nature of the covenant made with the Jewish people. This supersession of supersessionism, he argues, represents a highly significant rejection of centuries of Catholic theology. Drawing on the work of Kendall Soulen, he distinguishes between different kinds of supersessionism (economic; punitive; structural) and asks whether the text's substitution of 'fulfilment' for supersession can escape all its various forms: he suggests it cannot. Against the grain of the document, he concludes that a mild form of supersessionism is in fact definitionally intrinsic to Christianity.

Rabbi Jonathan Magonet notes the importance of not forgetting the background of centuries of hatred prior to the relatively recent rapprochement and collaboration between the faiths, and underscores the quality of teshuvah, turning or repentance, for all initiatives of learning and hope. Significantly he questions the document's blunt understanding of the Jewish covenant whose irrevocability it promotes. He argues that the document overemphasizes the universality of the Abrahamic covenant while forgetting the nature of the covenant with Moses on Mount Sinai. The latter shows that the covenantal relationship with the Jewish people is not just legal, but also one of chesed, loving mutuality between free partners: there is a significant commitment to freedom here. This article makes clear once again that the precise differences between faith traditions need to be explored and cherished on their own terms.

Those differences have frequently been described in familial or fraternal metaphors even before Nostra Aetate. Anna Sapir Abulafia insists that 
these should be avoided, especially the image of Israel and the Jewish people as 'elder brother' to Christianity, as this summons up the anti-Jewish rhetoric inspired by interpretations of the story of Esau and Jacob, the historical phenomenon of 'Jewish service', and the underlying dynamic of supersessionism. Along the way she encourages a balanced historical view of the relations between faith traditions, noting that the many massacres and expulsions notwithstanding, Jews and Christians have lived side by side in many contexts through the centuries. Nevertheless, like Magonet, she seeks more precision from the text as to what it means by 'Israel' and 'the Jews': are these defined vis-à-vis their Hebrew Bible roots, or with present-day Jews in mind, or even eschatologically?

The global religious and political landscape has been dramatically transformed in the fifty years between Nostra Aetate and 'The Gifts and the Calling of God are Irrevocable', primarily for good but also for ill. The co-opting of religion by extremist movements around the world in recent times highlights the huge contemporary importance of better and deeper understandings of religious difference beyond noxious mutual exclusion. It is our hope that the nuanced reflections of these articles, which explore the Catholic-Jewish encounter, further that aim.

Philip McCosker is Director of the Von Hügel Institute for Critical Catholic Inquiry at St Edmund's College, Cambridge, and Departmental Lecturer in Modern Theology in the Faculty of Theology and Religion, Oxford.

Ed Kessler MBE is Founder Director of the Woolf Institute, Fellow of St Edmund's College, Cambridge and a leading thinker in interfaith relations, primarily Jewish-Christian-Muslim relations. 